The Classical Quarterly

http://journals.cambridge.org/CAQ

Additional services for The Classical Quarterly:

Email alerts: $\underline{\text { Click here }}$

Subscriptions: $\underline{\text { Click here }}$

Commercial reprints: Click here

Terms of use : $\underline{\text { Click here }}$

\title{
IPHIGENIA'S DREAM IN EURIPIDES' IPHIGENIA TAURICA
}

\section{CAROLINE P. TRIESCHNIGG}

The Classical Quarterly / Volume 58 / Issue 02 / December 2008, pp 461 - 478

DOI: 10.1017/S0009838808000554, Published online: 16 December 2008

Link to this article: http://journals.cambridge.org/abstract S0009838808000554

How to cite this article:

CAROLINE P. TRIESCHNIGG (2008). IPHIGENIA'S DREAM IN EURIPIDES' IPHIGENIA TAURICA. The Classical Quarterly, 58, pp 461-478 doi:10.1017/S0009838808000554

Request Permissions : $\underline{\text { Click here }}$ 


\section{IPHIGENIA'S DREAM IN EURIPIDES' IPHIGENIA TAURICA*}

\section{INTRODUCTION}

In the prologue to Euripides' Iphigenia Taurica, Iphigenia tells a dream she had the previous night. In her dream, her house in Argos collapsed completely apart from one pillar, which she sprinkled with water. Iphigenia interprets this dream to mean that her brother Orestes is dead: she believes that the pillar refers to Orestes and her sprinkling of the pillar to her Taurian duty of consecrating foreigners for sacrifice. In the next scene, Orestes and Pylades appear on stage and the audience immediately sees Iphigenia's interpretation disproved. Orestes and Pylades are caught by the Taurians and brought before Iphigenia who does not recognize them. When Iphigenia hears that her brother is alive, she discards the dream as false, but the audience is bound to think the dream will come true, because Iphigenia is about to sprinkle her brother for sacrifice. The audience's expectation about the dream's prophecy is not fulfilled, however, for Orestes and Iphigenia recognize each other just in time. The audience at this point can draw two different conclusions: either the dream has not proved true or its interpretation of the dream is wrong and must be adapted in such a way that the dream does come true. In this article, I will deal with the complex dramatic function of the dream in the $I T$ and specifically with the distinct reactions of the audience and Iphigenia.

Though agreeing on Iphigenia's misinterpretation, secondary literature offers different views on the true meaning of the dream. William Messer thinks Iphigenia's dream to be true, but he does not explain how the dream is fulfilled if correctly interpreted. ${ }^{1}$ Anne Burnett, however, considers the dream false and unrelated to the second part of the play after Iphigenia's and Orestes' recognition. She believes that the dream prophesies Orestes' sacrifice by Iphigenia and threatens to be realized because of Iphigenia's misinterpretation. Burnett relates the dream to the theme of $\tau \dot{v} \chi \eta$ in the play and considers it to be 'the motive force in the counter-plot that rose against the gods' rescue plans'. ${ }^{2}$ Because of the convention that all dreams in literature prove true or significant, I think that it is more likely that the audience is inclined to adapt its interpretation.

George Devereux analyses the elements of the dream itself in detail from a psycho-analytical point of view. He connects the dream to the other dreams in

* I should like to thank André Lardinois and Ineke Sluiter for their valuable suggestions at different stages of this article, which began as an MA thesis supervised by Ineke Sluiter at Leiden University. I presented an abbreviated version at the 136th Annual Meeting of the American Philological Association held in Boston (January 2005).

1 W.S. Messer, The Dream in Homer and Greek Tragedy (New York, 1918), 91-6.

2 A.P. Burnett, Catastrophe Survived. Euripides' Plays of Mixed Reversal (Oxford, 1971), 69-70. Cf. D.J. Conacher, Euripidean Drama. Myth, Theme, and Structure (Toronto, 1967), 305 who simply speaks of a 'deceptive dream', R. Lennig, Traum und Sinnetäuschung bei Aischylos, Sophokles, Euripides (Berlin, Diss., Eberhard-Karls-Universität Tübingen, 1969), 156-64 arguing that Orestes' consecration for sacrifice is not presented in the dream as what will be fulfilled but as the threatening alternative to the recognition, and C.H. Whitman, Euripides and the Full Circle of Myth (Cambridge, MA, 1974), 8. 
Euripides' plays (Hecuba and Rhesus) and considers the three dreams as 'variations by the same "composer" - on a single theme: on that of the so-called "primal scene", which is the child's real or fantasised, but always anxiety-distorted, experience of his parents' coitus'. ${ }^{3}$ This rather controversial approach has been criticized among others by Jürgen Schwindt. He argues against the applicability of psycho-analysis to dreams in ancient literature by referring to Sigmund Freud who states that one is generally unable to interpret someone else's dream when the dreamer is unwilling to betray the unconscious thought behind the dream content. ${ }^{4}$

Schwindt himself applies an intertextual approach, comparing Iphigenia's dream and Penelope's dream in Homer, Odyssey 19.535-69. His interpretation of the dream is not entirely satisfying. According to him, the message of the dream is that Orestes is alive though in great danger. The dream turns out to be a true prediction; he concludes by quoting Eleanor Cederstrom: '[Iphigenia] recognizes her brother in the nick of time, saves him from sacrifice so that he is, after all, the last remaining "pillar" of the House of Atreus'. ${ }^{5}$

Martin Cropp, finally, recognizes the dream's complex dynamic function in his commentary on the play: 'The risk that Iphigenia will kill her brother is made vivid in the dream (42-58) which shows her preparing to sacrifice him and so sets a puzzle: how can the dream be fulfilled without her actually killing him? Her own misunderstanding of the dream complicates this problem, for so long as she thinks Orestes is dead she cannot begin to guess that he is one of her prisoners, and indeed is the more determined to kill him because of her own grief'. Cropp is one of the very few who relate the dream to the mock purification, but he does not explain when or how the audience could come to such a conclusion. ${ }^{6}$

In this article, I will focus my attention on the complex dramatic function of Iphigenia's dream in Euripides' IT especially in relation to the audience's shifting interpretation of the dream, an aspect which has been either overlooked or left unexplained up until now. The dream influences Iphigenia and the plot, but it also raises questions and thwarts the audience's expectations. In the first section, a linear analysis of the plot, I intend to show that from the prologue onwards, a wedge is driven between Iphigenia and the audience, based on Iphigenia's incorrect interpretation of the dream and the audience's superior knowledge that Orestes is alive. The

${ }^{3}$ G. Devereux, Dreams in Greek Tragedy. An Ethno-Psycho-Analytical Study (Berkeley and Los Angeles, 1976), 259-317, at 259.

4 J.P. Schwindt, 'Tragischer und epischer Traum: Euripides, Iph. Taur. 42-64 und Homer, Od. $\tau$ 535-69', Hermes 126 (1998), 1-14, at 1. For other critical remarks on a psycho-analytical approach of dreams in ancient literature (especially Penelope's dream in Homer, Od. 19), see A.H.M. Kessels, Studies on the Dream in Greek Literature (Utrecht, 1978), 93-4 and L. Pratt, 'Odyssey 19.535-50: on the interpretation of dreams and signs in Homer', CPh 89 (1994), $147-152$, at 148-9 with further bibliographical references.

${ }^{5}$ Schwindt (n. 4), at 13 and E.S.R. Cederstrom, $\Sigma M I K P O I$ 1OГOI. A Study of the Nature and Function of Dreams in Greek Tragedy (Ann Arbor, Diss., Bryn Mawr College, 1972), at 56.

${ }^{6}$ M.J. Cropp (ed., trans.), Euripides: Iphigenia in Tauris (Warminster, 2000), at 34, cf. his commentary on IT 42-66 (pp. 175-6). The anonymous referee drew my attention to M. Wright, Euripides' Escape-Tragedies. A Study of Helen, Andromeda, and Iphigenia among the Taurians (Oxford, 2005), which succinctly connects the dream to the mock purification at 287-8. Further references to discussions of Iphigenia's dream can be found in C. Walde, Die Traumdarstellungen in der griechisch-römischen Dichtung (Munich and Leipzig, 2001), 157-74. P. Kyriakou, A Commentary on Euripides' Iphigenia in Tauris (Berlin and New York, 2006), appeared after submission of this article; I have incorporated several points of interest from this full-scale commentary, though many other references to this work would probably be possible. 
next section is concerned with the dream's complex dramatic and thematic role. The dream creates a suspense which lasts till the end of the play and has an ambiguous function. An anxious or ominous characterization of the dream is understandable because of the usually malignant reputation of dreams in Greek tragedy and the ominous images in Iphigenia's dream, but it is difficult to connect this to the dream's 'friendly' fulfilment. Its complexity and obscurity make the audience experience the difficulties of interpretation, which relates to one of the main themes of the play, namely the human limitations in understanding the divine.

\section{SHIFTING EXPECTATIONS: A WEDGE BETWEEN AUDIENCE AND CHARACTERS}

Iphigenia's dream influences the plot in two different ways. On the one hand, the dream influences the characters. As long as Iphigenia believes (her interpretation of) the dream to be true, she acts upon it: the dream has made her aggressive towards strangers, as she herself claims, and it poses an impediment to the recognition, because it almost prevents her from fetching the letter. The third stasimon shows that the chorus, too, has discarded the dream as false, though it only knows Iphigenia's interpretation and not the dream's actual content. On the other hand, the dream influences the audience: it raises questions and expectations. As the plot moves forward, the audience needs to adapt these in order to find a fulfilment of the dream in a process of gradual unfolding.

I will give a linear analysis of the dream's influence on the plot. This will bring into relief the wedge between the audience and the play's characters Iphigenia and the chorus. At the same time, one will be able to see how the two different perspectives act upon each other. The linear analysis is divided into five parts. The first part examines the omissions and weaknesses in Iphigenia's interpretation and maximizes the possible interpretations that the audience may entertain during the prologue. The second part shows how until the recognition, a game is played with the suspense raised by the possibility that Iphigenia will sacrifice her own brother. Finally, the impending sacrifice is thwarted and the audience can find a new possibility to interpret the dream in relation to the mock purification, which is dealt with in the third part. The fourth part contains a discussion of the third stasimon, which offers an aetiology of dreams, in relation to the dream's function in the plot. The last part of the linear analysis is concerned with the outcome of the play and the dream's final auspicious fulfilment.

\section{Omissions in Iphigenia's interpretation and possible interpretations of the dream by} the audience in the prologue (1-122)

The plot of the IT deals with the aftermath of Iphigenia's sacrifice in Aulis. In this version of the myth, Artemis had saved Iphigenia in Aulis and put a deer in her place without being noticed. Artemis then settled her in the land of the Taurians, near the Black Sea, where she has to sacrifice to her all foreigners who visit this barbaric region. The first part of the prologue is a speech delivered by Iphigenia, who is on stage alone. Near the end of her speech she tells of her dream, 42-58:

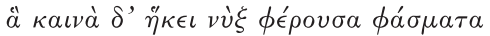

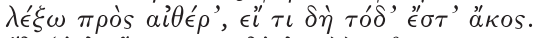

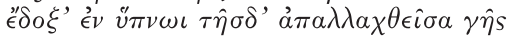

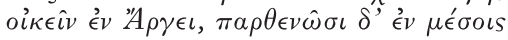




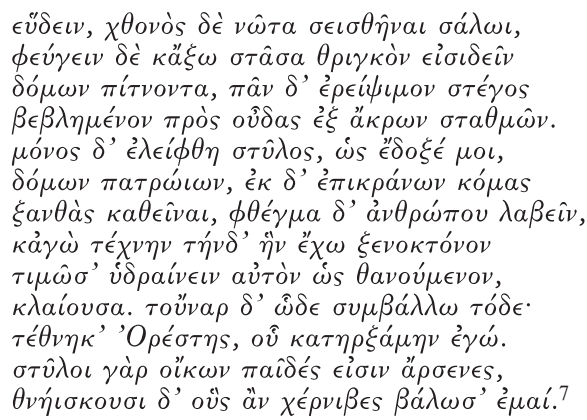

Now I will tell to the sky the strange new dreams this night has brought me - in case this can be a cure for them. I seemed in my sleep to be removed from this land and living in Argos. As I slept there in the midst of the girls' apartments, the earth's surface seemed shaken by a tremor. I seemed to flee, and standing outside I seemed to see the cornice of the palace falling, and the whole roof, from column-tops down, thrown in ruins to the ground. One pillar alone was left, as it seemed to me, from our ancestral palace, and from its head it seemed to grow auburn hair, and take a human's voice. So I, observing this stranger-killing art of mine, seemed to sprinkle it with water as one about to die, while weeping. Now this is how I interpret the dream: Orestes is dead; he was the one I consecrated. For male children are the pillars of their houses, and all those touched by my holy waters die. ${ }^{8}$

Iphigenia tells her dream to the sky to avoid the evil implied in the dream. ${ }^{9}$ This is a common apotropaic act, but here it also functions as a dramatically interesting device: it creates the exceptional situation with regard to dream scenes, that except for one character only the audience knows the dream's content, because the dream is not told again after the prologue. No other character, not even the chorus, can therefore provide a different interpretation of the dream. An audience may look, however, for another interpretation, because of the convention that dreams in literature are ambiguous and often initially misinterpreted by their dreamers but ultimately prove true or at least significant in a literary sense. ${ }^{10}$ In this play, the audience is encouraged to do so, because Iphigenia does not explain the elements of her dream fully or convincingly, and because the audience sees her interpretation disproved when Orestes enters the stage.

Iphigenia interprets only two elements of the dream: the sole pillar left standing

${ }^{7}$ Two more lines follow in the manuscripts, but their authenticity is disputed. Quotations from this play have been taken from Diggle's edition (Oxford, 1981) unless noted otherwise.

${ }^{8}$ The translations have been taken from Cropp (n. 6) with adaptations. Schwindt (n. 4), 9 discusses several details in translations of the dream.

${ }^{9}$ On this act see Cropp (n. 6), on IT 42-3 (p. 176) and Kyriakou (n. 6), on IT 42-3 (p. 64). On $\kappa \alpha \iota v \alpha$ ('new' or 'strange'), which may bear a bad connotation, see Walde (n. 6), 159, n. 30 and Kyriakou, ibid.

${ }_{10}$ The reader is expected to look for the meaning of a dream, even when the dreamer within the story does not believe his dream to be significant. At the literary level, dreams are always significant: they have a function within the literary work. Cf. R.B. Rutherford (ed.), Homer: Odyssey. Books XIX and XX (Cambridge, 1992), on Od. 19.560-1 (p. 196) on Homeric dreams. Some dreams in Herodotus are not taken seriously by their dreamers, but they nevertheless prove to be true, see I.J.F. de Jong, 'Herodotus and the dream of Cambyses (Hist. 3.30, 61-65)', in A.P.M.H. Lardinois, M.G.M. van der Poel, V.J.C. Hunink (edd.), Land of Dreams. Greek and Latin Studies in Honour of A. H. M. Kessels (Leiden and Boston, 2006), 3-17, at 7 (esp. nn. 11 and 12). Dreams in tragedy seem to have a more ominous and malignant character, cf. the dreams in Aes. Persae, Choephori, Soph. Electra, Eur. Hecuba and Rhesus. Their messages contain misery for their dreamers: they are disguised in grim images that the dreamer cannot always grasp. 
and her sprinkling of this pillar. The pillar stands for Orestes. Iphigenia usually sprinkles someone who is going to die, but she concludes that Orestes is already dead. Note the difference between the perfect $\tau \epsilon^{\prime} \theta \nu \eta \kappa \epsilon(56)$, the present $\theta \nu \eta_{\iota} \sigma \kappa o v \sigma \iota$ (58), and the future tense $\theta$ avov́ $\mu \epsilon \nu o v(54)$ : someone who is sprinkled, is not dead yet, but will die. Iphigenia, however, does not take the dream as a warning or prophecy concerning the future, but as a message about the past and present situation. Neither does she make a connection between Orestes' presumed death and herself.

In her explanation she omits among other things the fact that the house collapses but the pillar is still standing. A logical interpretation of the standing pillar is that Orestes is still alive. This interpretation is confirmed to the audience when Orestes enters the stage alive with his comrade Pylades (67), after Iphigenia has left. Seeking salvation from the Erinyes for killing his mother, Orestes has been told by Apollo's oracle to come to the land of the Taurians and steal the statue of Artemis. The story lines of brother and sister converge in this play. The entrance of Orestes causes a difference of knowledge between Iphigenia and the audience, a well-known literary device to create dramatic irony and suspense. This difference, or wedge, will grow as the plot moves forward.

As a result, it is quite easy for the audience to come to another interpretation of Iphigenia's dream, making use of its superior knowledge. In Iphigenia's absence, the audience finds out that Orestes is alive and that Agamemnon and Clytemnestra have been murdered. So the audience is, unlike Iphigenia, able to explain the collapse of the house as the killing of Agamemnon and Clytemnestra and the standing pillar as Orestes' survival. The beginning of the dream relates to the past when Iphigenia was still at home in Argos. The earthquake that forced Iphigenia out of the house could refer to the pretence about a wedding with Achilles in Aulis, which Iphigenia previously spoke about in the prologue (22-5). ${ }^{11}$ Iphigenia's oversight of this trick is possibly symbolized in the dream by her being asleep (she was not aware of what was happening). ${ }^{12}$ During her absence from the house, which may refer to her absence from Greece, the house collapsed completely. The $\theta \rho$ ско́ s that falls may symbolize the father of the house, Agamemnon, who is killed by Clytemnestra because of his sacrifice of Iphigenia. ${ }^{13}$ It is easier for the audience than for Iphigenia to explain this part of the dream, because the audience knows what has taken place in Argos after Iphigenia's sacrifice. It is significant then that Iphigenia sees the collapse in her dream. It is also significant that in the dream a connection is made between Iphigenia's sacrifice and her parents' death: the earthquake causes both Iphigenia's departure and the ruin of the house. The audience knows this connection from other plays but it is nowhere made explicit in this play: Clytemnestra's motive for killing Agamemnon is suppressed. ${ }^{14}$

11 Cf. Artemidorus Daldianus on earthquakes in his book on dream interpretation from the second century A.D., Oneirocritica, 2.41 (ed. Pack [1963], 177, 3-8) and 4. prooemium, lines 97-101 (Pack, loc. cit., 240, 11-3). Devereux (n. 3), 291 ascribes the earthquake to Poseidon, the Earth Shaker. Poseidon is mentioned twice in the IT, by the messenger (1415) and Athena (1444), cf. Cropp (n. 6), ad loc.

12 On Iphigenia's sleeping in the dream see Devereux (n. 3), 273.

13 Cf. Artemidorus 2.10 (ed. Pack [1963], 116, 6-14), who mentions cornices and pillars with a reference to $I T 57$, discussing the symbolic meanings of burning parts of a house.

${ }^{14}$ Cf. 552-9, 924-8. An explicit expression would have complicated the situation: it would have emphasized that the murders of Agamemnon and Clytemnestra, and the prosecution and purification of Orestes are all occasioned by Agamemnon's sacrifice of Iphigenia to Artemis, which turns out to be only a sham sacrifice. The suppression of Clytemnestra's motive makes her deed 
The remaining pillar is interesting for other reasons as well. Blond hair, кó $\mu a s$

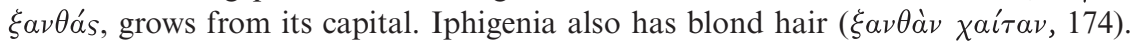
Perhaps by similarities in their masks, the audience will see the likeness of Orestes' and Iphigenia's hair when they meet, which 'will add to the poignancy of their not recognizing each other, especially since hair was featured in the recognitions in Aeschylus' Choephori (183-200, 225-234) and Euripides' Electra (513-531)'. ${ }^{15}$ Although Iphigenia saw Orestes' hair in her dream already and immediately related the pillar to Orestes, she fails to recognize him the moment she meets him. ${ }^{16}$

The pillar's blond hair is sinisterly echoed by Pylades who uses the adjective $\xi \alpha \nu \theta o ́ s$ to describe the altar polluted with human blood (73-4): ${ }^{17}$

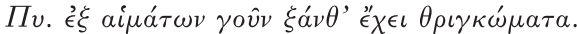

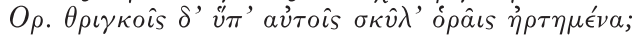

Pylad. 'It is - at least, its copings are brown with bloodstains'.

Orest. 'And under the copings themselves you see trophies hanging?'

The altar has $\xi \alpha \nu \theta \dot{\alpha} \theta \rho \iota \gamma \kappa \omega ́ \mu \alpha \tau \alpha$, 'brown copings', due to bloodstains from human

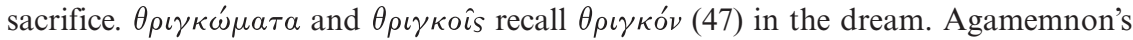
house in Argos, Artemis' temple in the Taurian land and Orestes have been stained with human blood. The blond hair growing from the pillar is perhaps not just a human sign but also reinforces the impression of pollution, which is after all an essential element in the play, since Orestes' pollution is his reason for coming to the Taurian land.

But what about the sprinkling of the pillar? How is this element of the dream to be explained? Because Orestes has landed in the Taurian land, it is possible that Iphigenia will sprinkle him and consecrate him for sacrifice. The expectation is raised that Orestes is on the verge of being sacrificed by his own sister. Such an outcome of the play, however, would give a rather odd twist to the known Orestes story. ${ }^{18}$ This

appear more horrible, while Orestes' revenge seems more justified, which on the whole makes the possibility of purification conceivable. Cf. F.I. Zeitlin, 'Redeeming matricide? Euripides rereads the Oresteia', in V. Pedrick and S.M. Oberhelman (edd.), The Soul of Tragedy. Essays on Athenian Drama (Chicago and London, 2005), 199-225, at 202 and 211, n. 19. Cf. Kyriakou (n. 6), 19. The anonymous referee points out that in the prologue to Eur. Orestes (26-7) Electra similarly suppresses Clytemnestra's motives, but in a self-conscious and rhetorical way.

${ }_{15}$ Cropp (n. 6), on IT 52 (p. 177). In Eur. El. both Orestes (515) and Clytemnestra (1071) are described as having blond hair.

${ }^{16}$ Cf. Aes. Choephori 168-234, where Electra immediately identifies the hair near Agamemnon's tomb with Orestes', but does not recognize him when she sees him. The situations in the two plays differ in that the lock of hair in Aes. Ch. makes Electra uncertain about Orestes' situation, while Iphigenia in the $I T$ believes with certainty that Orestes is dead because of the dream, which prevents her from connecting the stranger and her brother.

17 Whitman (n. 2), 5 and Walde (n. 6), 162 also notice the resemblance. Cf. Devereux (n. 3), 286-7: the colour $\xi \alpha \nu \theta$ ós occurs four times in the play $(52,73,173$ and 633), each time bearing ominous or funerary connotations. The dream carries many images with awful associations. Only the beginning consists of a serene scene with Iphigenia sleeping in her girls' chamber, which is then crudely disturbed by the earthquake. The remaining pillar may not only refer to a male child but may have funerary connotations as well, see Cropp (n. 6), on IT 50-2 (p. 177) with a reference to E.P. McGowan, 'Tomb marker and turning post: funerary columns in the archaic period', $A J A$ 99 (1995), 615-32.

${ }^{18}$ Cf. Kyriakou (n. 6), on IT 55b-58 (p. 66) who considers this apparent prediction of the dream as 'probably a teasing cue to the audience who may eventually imagine that Orestes' sacrifice will proceed to a much more advanced stage than it actually does before the recognition of the siblings or the intervention of a god who would interrupt the sacrifice'. On the play's myth, 
explanation therefore raises new questions for the audience, especially in view of the seemingly conflicting oracle of Orestes. Richard Hamilton remarks about the effect on the audience of Iphigenia's dream and Orestes' oracle in the prologue: 'Since both dreams and oracles are sanctioned communications from the gods, the audience would normally regard them both as true, but here that is impossible since they contradict each other. The dream, regardless of Iphigenia's interpretation of it, implies that Orestes will be sacrificed, whereas the oracle implies that he will be saved' 19

Iphigenia's dream may have an obscurer meaning than Orestes' oracle, but the oracle carries some ambiguity as well. Orestes refers to the oracle several times in the play. In the prologue he says the following, 85-92 (addressing Apollo in apostrophe):

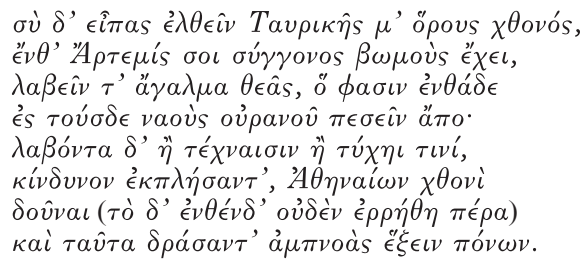

You said I must go to the borders of the Taurian land, where your sister Artemis possesses altars, and take the goddess's image which they say fell here into this temple from the sky - must take it by trickery or some stroke of luck, and then when I have seen the peril through, must give it to the land of the Athenians (of what should follow from that, nothing was said), and after doing this would have respite from my ordeals.

Cropp draws attention to the ambiguous phrase $\alpha \mu \pi \nu o \alpha ̀ s ~ \pi o ́ v \omega \nu$ ('respite from my ordeals', 92): for Sophocles' Heracles a similar promise means salvation through death (Soph. Trach. 76-81, 166-72, 824-6, 1169-73). ${ }^{20}$ Although Orestes remains alive in other plays, the phrase can - strictly speaking - mean death and has a sinister undertone at least. Moreover, Apollo does not tell how Orestes can accomplish his task ( $\left.\ddot{\eta} \tau \epsilon^{\prime} \chi \alpha \iota \sigma \iota \nu \ddot{\eta} \tau \dot{v} \chi \eta \iota \tau \iota \nu \iota^{\prime}, 89\right)$. Nor is it clear at this point how Orestes can bring about his salvation if he succeeds. What has Artemis' statue to do with his persecution by the Erinyes? It is no wonder then that Orestes has little faith in the oracle.

At the end of the prologue, the audience has been left with several questions concerning the further development of the play. How can both the dream and the oracle be fulfilled without Iphigenia killing her brother? Can the dream have an auspicious fulfilment at all, given the ominous reputation of tragic dreams? Could

see Burnett (n. 2), 73-5 and Cropp (n. 6), 43-56. For a detailed discussion of other striking features in the version of the myth in this play see Wright (n. 6), 56-157 at 133, who places the IT and Helen in the same trilogy and argues 'for perceiving Euripides' myths as unusual combinations of elements, rather than as original inventions or as direct borrowings from a single source'. He relates Euripides' special use of myth and its probably confusing effects on the audience to a main theme in the play, the limitations of human understanding, which I will discuss below, in part III.

19 R. Hamilton, 'Prologue prophecy and plot in four plays of Euripides', AJPh 99 (1978), 277-302, at 283. On the other hand, he admits that the deception 'embodies both the condition of the dream that Iphigenia sacrifice Orestes, and that of the oracle, that Orestes is polluted and needs purification by moving the statue' (at 288).

${ }^{20}$ Cropp (n. 6), on $I T 92$ (p. 180). Cf. Athena's words in the end, 1441b: $\tau \hat{\omega} \nu \nu \hat{v} \nu \pi \alpha \rho o ́ v \tau \omega \nu$

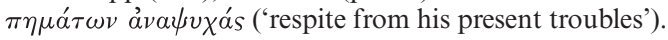


Orestes be on the verge of being sacrificed by his sister? What is the function of Iphigenia's striking misinterpretation in all this?

\section{Will Iphigenia sacrifice her brother? (123-772)}

Iphigenia mentions her dream three more times after the prologue: in the parodos (150-1), after hearing that two foreigners have been captured (348), and in her meeting with these men (569). In the parodos, which brings no relief, the chorus enters at Iphigenia's request: because of the dream (150-1), she grieves for Orestes and wants to pour libations for her supposedly dead brother together with the chorus. ${ }^{21}$

The fulfilment of the audience's expectation that Orestes will be sacrificed by his sister becomes more probable after the first messenger speech and Iphigenia's reaction to it (236-391). Two foreigners, whom the audience knows to be Orestes and Pylades, have been captured. Iphigenia says the dream has made her savage (348): she used to be full of pity towards foreigners who were about to be sacrificed, but now that her own brother is dead she will be unkind. Her reaction increases the suspense: the dream does not contain the message of Orestes' death but the prophecy of his death, a prophecy which seems to come true precisely because of Iphigenia's reaction to her (misinterpreted) dream. ${ }^{22}$

When Iphigenia meets the foreigners, her professed bitterness does not hold: she laments their fate (472-81, cf. Orestes' words in 482-3 and 490). ${ }^{23}$ Iphigenia's lamentation may cover a reference to the dream and even strengthen the audience's present understanding of the dream, because it seems she will indeed $\tau \epsilon \in \chi \nu \eta \nu \tau \eta^{\prime} \nu \delta \epsilon$

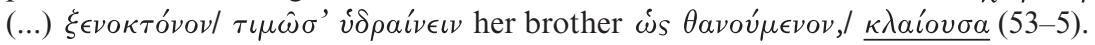

The foreigners refuse to reveal their identities, but in the end Iphigenia manages to elicit some information from the foreigner Orestes. Her words upon hearing that her

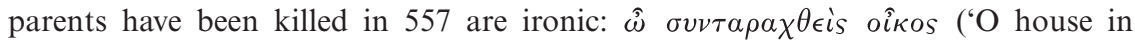
turmoil!'). ${ }^{24} \sigma v \nu \tau \alpha \rho \alpha ́ \sigma \sigma \omega$ means to 'throw into confusion or disorder' (LSJ s.v.) and $\tau \alpha \rho \alpha \dot{\sigma} \sigma \omega \omega$ is to 'stir' or 'trouble' both in a physical and in a metaphorical sense. The social disturbance of Iphigenia's house mirrors its symbolic equivalent in the dream, the disorder of the house caused by the earthquake (46-9). ${ }^{25}$

When she hears that Orestes is still alive, Iphigenia concludes that the dream was not true, 569:

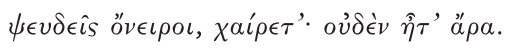

${ }^{21}$ Cf. Iphigenia's promise to the stranger Orestes in 630-5 to offer services when he has died.

${ }^{22}$ Walde (n. 6), 165 draws attention to the irony contained in Iphigenia's expressed feelings of revenge: wishing to sacrifice her relative Helen in the Taurian land, her words contain more truth than she is aware of, being on the verge of killing her brother. Next, her condemnation of human sacrifice somewhat releases the suspense: this person seems hardly able to kill Orestes.

${ }^{23}$ Devereux (n. 3), 283-4 seems to overlook this change in Iphigenia's attitude emphasizing Iphigenia's supposed aggression towards her brother and father. Iphigenia does show feelings of revenge, see Walde (n. 6), 165 and Cropp (n. 6), on IT 609-42 (p. 215). Cropp (n. 6), 34 takes no notice of Iphigenia's change either.

24 Though Iphigenia's words in 147-56 may have given the impression that she thinks she has lost her whole family and not only her brother, they should probably be taken metaphorically, in order to make sense of Iphigenia's surprise and shock on hearing of her parents' death at 543-9 and 555-7. She has completely failed to understand the dream.

25 The house is a familiar image of the family, cf. Orestes appealing to Iphigenia in $984 \sigma \hat{\omega} \sigma o \nu$

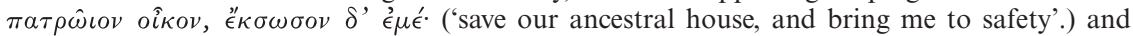

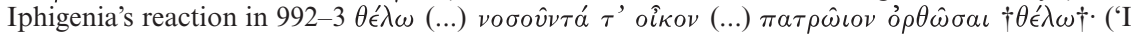
want to raise up our ailing ancestral house'). Also see Cederstrom (n. 5), 175-6. 
False dreams, fare well: you were nothing, then.

She puts the dream aside with as much certainty now as earlier on she was convinced of her own interpretation and her brother's death. Though dreams in ancient literature are notorious for their ambiguity, this is a remarkable statement: in extant Greek tragedy there is no parallel of someone who dismisses a dream he had himself as false in the end. ${ }^{26}$ As Jon Mikalson observes: 'The female chorus of Sophocles' Electra is prepared to doubt the prophetic power of all dreams and oracles if Clytemnestra's vision is not realized (498-502), but this mild challenge is met when Orestes slays his mother. Iphigeneia among the Taurians is unique in that the correct interpretation of a dream is never put forward by a character, and doubt is cast and left pending about the prophetic power of dreams in general'. ${ }^{27}$ The dream is not mentioned any more after this. The general theme of deceptive dreams is picked up in the third stasimon, but this specific dream is not referred to again.

Iphigenia's conclusion to discard the dream as false, just when she hears Orestes is alive, is ironic. She thinks the misery is over, but for the audience the suspense grows: it is true Orestes is not dead, but he may die soon! Orestes, for his part, has lost all confidence in his mantic message as well, 570-5:

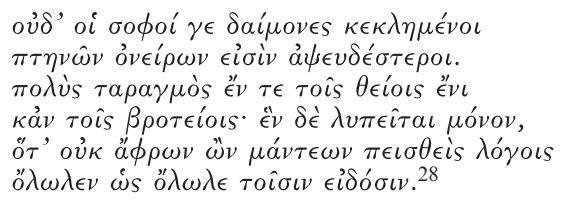

Nor indeed are the gods, though reputed to be wise, any more infallible than flighty dreams. There is much turmoil in the divine and in human affairs; but he grieves over one thing only, when not through being foolish, but persuaded by seers' pronouncements, he is ruined as those who know of it know he is ruined.

While Iphigenia's expression of disbelief manifests relief, Orestes' words are full of bitterness.

Then for a moment it looks as if the expectation that Orestes will be sacrificed by his sister, is thwarted, because Iphigenia comes up with the plan to sacrifice Pylades

${ }^{26}$ Lennig (n. 2), 159. It is almost as if Iphigenia knows about her father's deceitful dream in Troy (Iliad 2) and therefore realizes that dreams may be false, cf. Walde (n. 6), 170. Zeus is responsible for the dreams' deceitfulness in both cases. For his role with regard to deceptive dreams in the $I T$, see below in the discussion of the third stasimon. According to Burnett, the dream and Iphigenia's quick rejection would have presented Euripides with a difficult problem, see n. 36 .

27 J.D. Mikalson, Honor Thy Gods. Popular Religion in Greek Tragedy (Chapel Hill and London, 1991), 104. In Soph. OT 981-2 Iocaste casts doubt upon Oedipus' oracle by claiming that dreams in which men sleep with their mothers have no meaning.

${ }_{28}$ Cropp's text (n. 6) has been printed except for lines 572-5, which he and Kovacs (Loeb edition, 1999) delete, but which I take to be genuine with Sansone (Teubner ed., 1981) and

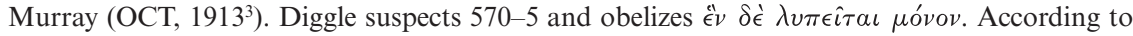
M.J. Cropp, 'Notes on Euripides, Iphigeneia in Tauris', ICS 22 (1997), 25-41 at 31, lines 572-5 do not 'fit Orestes' situation, for Orestes was advised not by seers but by Apollo himself (...)'. Though Cropp admits that Apollo is called a seer elsewhere in the play, he states without

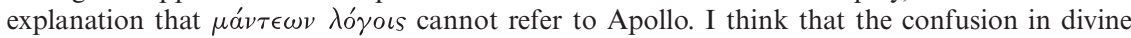
and human affairs mentioned in 572-3 is relevant for the following sentence, which alludes to Orestes' situation as an example to illustrate this confusion and in which both divine and human affairs are concerned. According to this line of reasoning, $\mu \alpha ́ \nu \tau \epsilon \omega \nu$ could refer to the god Apollo very well. 
only: she wants Orestes to return to Argos and to take a letter with him (578-96). However, she adjusts her plan after Orestes asks her to sacrifice him instead of Pylades. Iphigenia's reaction to Orestes' wish to be sacrificed is full of irony, 609-16:

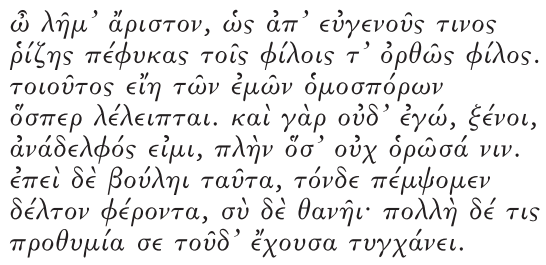

O excellent nature: what a noble root you have grown from! What genuine friendship are you showing to your friends! Would that my own surviving brother were like this! (For I too, strangers, do not lack a brother, except insofar as he is not in my sight.) But since this is what you want, he is the one I'll send to carry the letter, and you shall die. You're possessed by a great desire for this, for some reason.

Without knowing it she utters a wish to sacrifice her own brother. ${ }^{29} \lambda \epsilon \epsilon \epsilon \iota \pi \tau \alpha \iota$ (612) may echo the verb in the dream, which describes the remaining pillar: $\epsilon^{\prime} \lambda \epsilon \dot{\phi} \phi \theta \eta$ (50).

Thereupon Orestes asks Iphigenia who will do the sacrifice. It turns out that Iphigenia will not do the actual killing, 621-2:

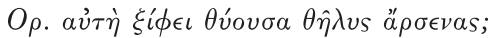

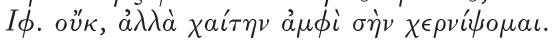

Orest. You'll kill me with the sword yourself, female killing male?

Iphig. No, but I'll sprinkle holy water around your hair.

The distinction between the act of sprinkling with water and the killing itself will become important when the audience intends to revise its interpretation of the dream. Besides, Iphigenia's referring to the victim's hair, $\chi \alpha i$ i $\eta$, recalls кó $\mu \propto \iota$ in the dream

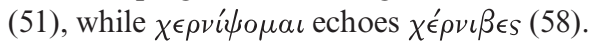

\section{Thwarted expectations: the audience needs to adapt its interpretation (773-1233)}

In spite of the expectations that have been raised, the anticipated outcome of the dream will not be fulfilled in the end: because Orestes and Iphigenia recognize each other just in time thanks to the letter (773-827), the expectation that Iphigenia may purify her brother for sacrifice is thwarted. The audience can draw two different conclusions from this unfulfilled interpretation of Iphigenia's dream: the dream has not proved true; or its expected interpretation of the dream has not come true and it has to adapt its interpretation and expectation of the dream in such a way that the dream proves to be true after all. On the basis of the aforementioned convention of literary dreams, I think it is more likely that the audience is stimulated and is inclined to adapt its interpretation. A new possibility for interpreting the dream comes up in Iphigenia's plan for escape (1029-88). She invents a mock ritual, a purification, which will give them the opportunity to escape. She says she has to clean Orestes, Pylades

29 See also Cropp (n. 6), on IT 609-42 and 612-13 (p. 215). Iphigenia shows feelings of revenge and considers herself as dangerous to her house (776-8), cf. nn. 22 and 23. She wants Helen and Menelaus to pay for Aulis (354-8, cf. 523-5). 
and the statue with seawater because they are polluted with bloodguilt. The plan almost fails, but the Greeks are rescued by Athena's intervention in the end.

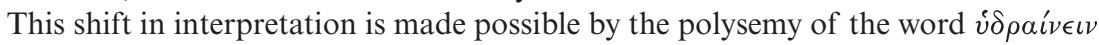
('to sprinkle', 54) in the dream. The act of sprinkling turns out to be a reference not to the purification of Orestes before he is sacrificed, but to Iphigenia's washing of Orestes with seawater. In the rest of the play other terms are used for the sprinkling of

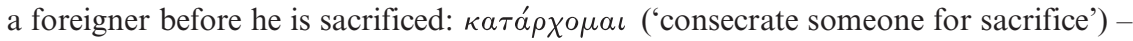

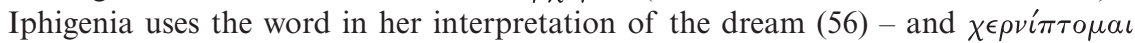
('sprinkle someone with holy water, purify or dedicate thereby'). ${ }^{30}$ These terms, in contrast to $\dot{v} \delta \rho i i^{\nu} \omega$, specifically denote the activity of consecrating the sacrifice. $\dot{v} \delta \rho \alpha^{\prime} \nu \omega$, on the other hand, derived from $v \delta \omega \rho$, just means to sprinkle with water and often refers to ritual cleansing in the other passages in which this rare verb is used..$^{31}$ And so, here too, in the end the sprinkling in the dream seems to refer to the purifi-

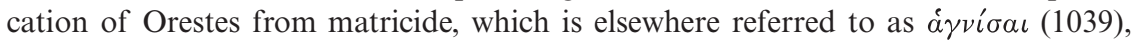

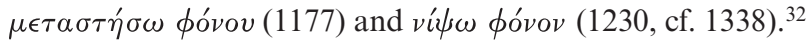

Something else, moreover, is striking about the word $v \delta \rho a i v \epsilon \iota v$ : the aspect or stem. A present aspect is used, while Iphigenia uses an aorist aspect in her interpretation of

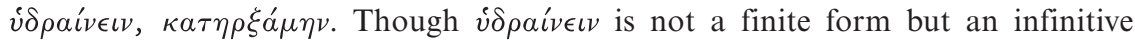
belonging to a series of infinitives depending on the aorist form ${ }_{\epsilon}^{\prime} \delta o \xi \epsilon(50)$, it is significant that precisely this last infinitive in a row has a present aspect instead of an aorist. A dream or, in general, a story that ends with a present aspect, is strange: the story has not been completed. One expects an aorist aspect to complete the story. Iphigenia sprinkles the pillar, but what happens next? The dream is an open-ended story, due to the present aspect of the verb. Iphigenia's sprinkling is not presented as a completed action whose meaning and function are certain. It is Iphigenia who links the act of $\dot{v} \delta \rho i^{\prime} \nu \epsilon \iota v$ to her duty of consecrating people for sacrifice, by using the aorist

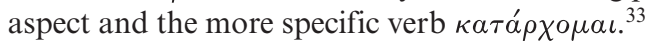

${ }^{30} \kappa \alpha \tau \alpha ́ \rho \chi о \mu \alpha \iota$ is also used by Iphigenia in 40 and by Thoas in 1154. $\chi \epsilon \rho \nu \iota \pi \tau о \mu \alpha \iota$ occurs in 622 , cf. $58 \chi \chi^{\prime} \rho \nu \iota \beta \epsilon s$, 'holy water for washing the hands'.

31 J. Diggle, 'Notes on the Iphigenia in Tauris', PCPhS 22 (1976), 42-5, at 42 (reprinted in his

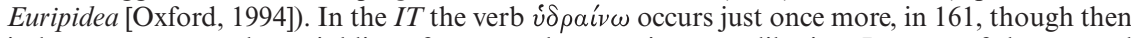
it does not concern the sprinkling of a person but pouring out a libation. Because of the unusual sense of the verb there, it has been proposed to alter the reading of L (ed. Diggle), see Cropp ( $\mathrm{n}$. 28), 26-7. Whitman (n. 2), 8, however, finds a connection with the dream: 'During the song, Iphigeneia performs funeral libations in absentia for her brother, but her use of the verb "to sprinkle," instead of "pour," oddly recalls the presacrificial rites she described in her dream. The irony of holding a funeral service for one who is not dead is thus delicately compounded with the irony of Iphigeneia's near-fulfillment of her dream'. Cf. Hamilton (n. 19), 284-5: 'When

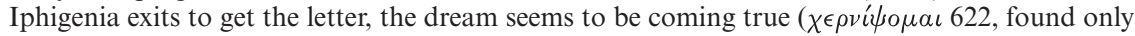
here in tragedy, recalls 58), and not only the dream but also Iphigenia's plan based on her faulty interpretation of it, for she promises to perform, like a sister (cf. 627), the customary funeral ritual $(632-5=159-66)$ after Orestes is killed'. For the other instances outside the $I T$ in which

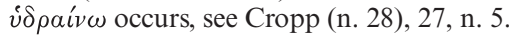

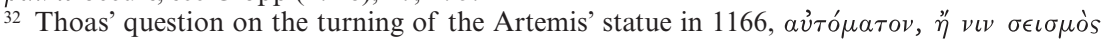
'́$^{\prime} \tau \rho \epsilon \psi \epsilon \chi \chi_{\text {ovós; }}$ ('Of its own accord, or did an earth-tremor turn it?'), recalls the earthquake in

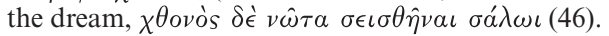

${ }_{33}$ Cf. C.M.J. Sicking and P. Stork, Two Studies in the Semantics of the Verb in Classical Greek (Leiden, New York and Cologne, 1996), 103-4. Lennig (n. 2), 158 has already observed the difference in aspect, but he has wrongly interpreted $v \delta \rho \alpha i v \epsilon \iota \nu$ as a praesens de conatu, meaning that Iphigenia does not really sprinkle Orestes with water, but only prepares to do so. Lennig thinks that the sprinkling functions as the threatening alternative to Orestes' and Iphigenia's mutual recognition, and does not pertain to the second part of the play, the intrigue. 


\section{The third stasimon: an aetiology of dreams (1234-83)}

Just as Iphigenia and Orestes leave to escape and the dream is going to be fulfilled, the chorus sings an aetiology of deceptive dreams. This third stasimon marks the wedge between the perspective of the characters, especially the chorus, and that of the audience. It is a hymn to Apollo, but its function and meaning are debated. ${ }^{34}$ The hymn contains an aetiology of how Apollo obtained the Delphic oracle and why dreams do not express themselves any more in unambiguously truthful and certain terms. Baby Apollo slew the monstrous serpent at Delphi and entered the oracle. This was the familiar version of the myth. The antistrophe contains an addition to this story, which was probably invented by Euripides himself. ${ }^{35}$ When Apollo had removed Themis, Earth retaliated by giving birth to dreams that told mortals what had happened and what would happen. Zeus helped Apollo, deprived of his prerogative, by ending the dreams' voices and taking away the truth from mortals. This ode is about a conflict between older, chthonic, female gods and younger, Olympian, male ones. The mantic power, the means of communication between mortals and gods, is at stake. The takeover of the Delphic oracle can be seen as a shift in power, a displacement of chthonic deities by Olympian ones.

At first sight, the stasimon confirms the reliability of Apollo's oracle and explains why dreams are deceptive. It seems to suppress the misleading aspect of oracles. Christiane Sourvinou-Inwood claims, starting from the ambivalent character of prophecies, that in the third stasimon and in the whole play the negative side of prophecies is attached to Gaia's dreams (the dreams in the third stasimon originated from malice and were associated with darkness and night, while Iphigenia's dream was misleading and limited by its lack of advice). Apollo's oracle is presented as the opposite of Gaia's dreams and therefore depicted in a positive way. ${ }^{36}$

However, several elements in the ode and in the play as a whole complicate this neat opposition. Apollo's assumption of power in Delphi is not described as a glorious success. The baby god cannot cope with Gaia's revenge on his own but needs his father's help. ${ }^{37}$ The confidence in divine help for humankind, which may appear at

34 On this stasimon see Cropp (n. 6), on IT 1234-83 (pp. 247-9) with earlier bibliographical references and Kyriakou (n. 6), on IT 1234-83 (pp. 391-4). Cf. Zeitlin (n. 14), 204-8.

${ }_{35}$ Cropp (n. 6), on IT 1234-83 (pp. 247-9). C. Sourvinou-Inwood, 'Reading' Greek Culture. Texts and Images, Rituals and Myths (Oxford, 1991), 227-32 gives a mythological analysis. Note the present $\theta \alpha \dot{\alpha} \sigma \epsilon \epsilon s$ at the end of the strophe in 1254. This is the current situation. With regard to the content and the familiar versions of the myth, the choral ode could have ended here. Cf. Kyriakou (n. 6), on $I T 1250-8$ (p. 399).

${ }^{36}$ Cf. Burnett (n. 2), 69-70 who thinks that 'the dream offered a difficult problem, for its tremendous influence had to be dispelled before Iphigeneia could produce her cherished letter and get the recognition under way. ... In the final choral ode he [Euripides] treats the dream, its error, and what has superseded it, explaining how a vision could be so hallucinating, so nearly prophetic, and so quickly repudiated. (...) Dreams are thus like chance events; they belong among the random things of the world which, this myth suggests, are the vestigial evidences of a pre-Olympian time. A true understanding of the past, the present or the future can come only from the power that is superior to both time and chance, and so is to be got only at the oracular shrines of the Olympian gods, by their aid and favour'.

37 This motive, the failure to accomplish something at the first go and the need for divine help, is important considering that this part of the ode is probably Euripides' own invention, and given its parallels in the rest of the play, e.g. in the escape plan (the trick is seen through and Athena needs to interfere) and Orestes' rescue by Apollo from the Erinyes (Orestes' pursuit has not been stopped completely at his trial in Athens). Afterwards, in the light of the escape, the strophe in the third stasimon with its familiar content confirms the expectation of the chorus and of the audience, while the antistrophe turns out to foreshadow the unexpected development in the exodus, as the initial success that is set back detracts from Apollo's praise, see M. Hose, Studien 
first sight from this ode, may account for the chorus's perspective: the chorus hopes that the escape plan will succeed and that Apollo's oracle will be fulfilled. ${ }^{38}$ The chorus praises the god in order to ask for his help during the escape. ${ }^{39}$ As far as the chorus knows, the dream has simply been deceptive. As such, the stasimon illustrates the chorus's (mistaken) expectation and perspective at this moment in the plot.

Furthermore, the ode contains some ambivalent phrases. Apollo's foremost intention does not seem to help humanity but to have the mantic monopoly in order to gain $\pi \circ \lambda \hat{x} \chi \rho v \sigma \alpha \lambda \alpha \tau \rho \epsilon v_{\mu \alpha \tau \alpha}$ ('worship rich in gold' 1275) and $\tau \iota \mu \alpha$ s ('honour' 1280). ${ }^{40}$ Furthermore, the ode carries a curiously playful undertone because of its emphasis on Apollo's young age. It adds to an impression that the younger Olympian gods do not care that much for struggling humans. ${ }^{41}$

Ironically, just as the chorus sings an aetiology about the deceptiveness of dreams, the dream is fulfilled. From the audience's point of view, the dream and the oracle in the play initially seem to contradict each other, but in the end they prove each other's complement. The stasimon explains the chorus's position and as such, it sheds light on the wedge between the characters and the audience concerning the interpretation of the dream.

Unlike Orestes' oracle, which he obtained from Apollo in the god's sanctuary at his request, Iphigenia's dream comes uninvited and its sender remains obscure. According to Iphigenia, the night has brought new visions (42). The third stasimon offers information on the origin and nature of dreams. It regards Gaia as the sender of dreams and the only reason for the audience to think otherwise about Iphigenia's dream is that Gaia does not seem to play any role in the plot. The only god who may have sent the dream in her own interest is Artemis. ${ }^{42}$ She has some chthonic features that allow for an association with dreams. ${ }^{43}$ Her interest would be a wish to prevent a real sacrifice of Orestes, in the same way as she has (wished and) prevented the sacrifice of Iphigenia by means of a mock sacrifice. Her inscrutable wishes and intentions concerning human sacrifice are the equivalent of the ambivalent images in the dream. Furthermore, this would provide a 'sibling' symmetry: Orestes receives an oracle from Apollo, Iphigenia receives one from Artemis.

zum Chor bei Euripides (Stuttgart, 1991), vol. 2, 25. For a slightly different perspective on setbacks in the play, see Kyriakou (n. 6), 16-17.

${ }^{38}$ In the second stasimon, the chorus already assumes a safe homecoming for Iphigenia under Apollo's guidance. Cf. Orestes' words in 1016.

${ }^{39}$ Cropp (n. 6), on IT 1234-83 (pp. 247-9) and W. Furley, 'Praise and persuasion in Greek hymns', JHS 115 (1995), 29-46, at 38.

40 Cf. Cropp (n. 6), 39 and on $I T$ 1234-83 (pp. 247-9).

${ }^{41}$ Cf. Cropp (n. 6), on IT 1234-83 (p. 248): 'That he kills the dragon as a babe in arms adds charm and humour to the story, but it also affirms the superhuman power of the Olympian god. ... The humour and playfulness of the ode's narrative hint at a divinely sponsored fortune which is unpredictable yet possibly beneficent, and more burdensome to weak humans than to carefree gods'. O. Panagl, Die 'dithyrambischen Stasima' des Euripides. Untersuchungen zur Komposition und Erzähltechnik (Vienna, 1971), 119-39, at 132 considers the stasimon as a satire on Zeus' and Apollo's sense of justice and thinks that Euripides uses it as a means 'um in der beibehaltenen äusseren Form einer als Hymnus griechischer Frauen gestalteten Mythenerzählung, den Zweifel des eigenen Herzens an den besungenen Göttern zu bergen'. D. Sansone, 'The sacrifice-motif in Euripides' IT , TAPhA 105 (1975), 283-95 considers the play a reaction to and a rejection of the theology in Aeschylus' Oresteia.

${ }^{42}$ Hamilton (n. 19), 287-8 also finds a connection between Artemis and the dream. On the sender of the dream cf. Schwindt (n. 4), 7-8.

${ }^{43}$ On Artemis in the IT see C. Sourvinou-Inwood, 'Tragedy and religion: constructs and readings', in C. Pelling (ed.), Greek Tragedy and the Historian (Oxford, 1997), 161-86, at 171-5. Some chthonic features of Artemis: her association with the moon (cf. IT $\phi \omega \sigma \phi o ́ p \omega \iota \theta \epsilon \hat{\alpha} \iota$, 'light-bearing goddess', 21) and with the moon- and underworld goddess Hecate. 
In the light of the third stasimon, Gaia or Artemis as the dream's sender is an obscure but not an ominous messenger, as one would perhaps expect from a chthonic power. The dream's malevolent appearance has no chthonic cause but is due to Zeus's intervention. Zeus changed the form of dreams in order to enhance the competitiveness of his son's oracles. It is ironic, then, that it is precisely the dream's misleading form that impedes the oracle's fulfilment (or human faith in oracles at least). From this point of view, Apollo does not have the mantic monopoly, nor has it become easier for humankind to gain an insight into divine intentions and prophecies because of Apollo's ambition.

The tension between dreams and oracles mirrors the tension between the chthonic and the Olympian. Orestes seeks release from the Erinyes with the help of Apollo. The barbarian Artemis asks for human sacrifice but she becomes more civilized. Chthonic and Olympian powers do not always stand in opposition to each other, however. They can complement each other. This is also illustrated in Aeschylus' Choephori where both Apollo and the Erinyes demand revenge on Clytemnestra, though they are opposed to each other in the subsequent play, when Apollo wants to rescue Orestes from the Erinyes who are sent by Clytemnestra. ${ }^{44}$

How did dreams originally communicate their messages to people? In line 1267 we are told that dreams "̈ $\phi \rho \alpha \zeta o \nu . \phi \rho \alpha ́ \zeta \omega$ is ambiguous as it can mean both 'show' and

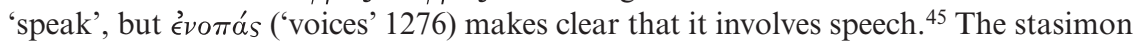
suggests that Zeus stopped the dreams from speaking, ${ }^{46}$ the way they still can in the ancient dream speeches in Homer. ${ }^{47}$ It may contain a reference to Iphigenia's dream: the pillar gets a $\phi \theta \dot{\epsilon} \gamma \mu \alpha \dot{\alpha} \nu \theta \rho \omega \dot{\pi} \pi$ ov ('human's voice' 52), but she has presumably not heard the pillar's words. ${ }^{48}$ Otherwise the pillar (Orestes) could have warned her, like the eagle (Odysseus) who could offer an explanation to Penelope in her dream. People used to be visited in their dreams by persons who spoke (compare most dreams in Homer, which are messenger dreams), but now only symbolic dreams are left, which

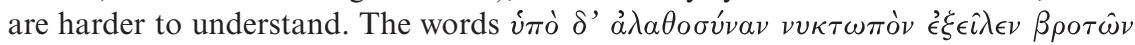
bear an ambiguity that can be connected to the wedge between the audience and the chorus. This phrase can on the one hand indicate the falsehood of dreams, and on the other hand emphasize that the truth in dreams is concealed from mortals (but may still be there). ${ }^{49}$

To conclude, the third stasimon illustrates the ambiguity of dreams by explaining

${ }^{44}$ A.F. Garvie (ed.), Aeschylus: Choephori (Oxford, 1986), xxxi-xxxiii with further bibliographical references. Cf. R.P. Winnington-Ingram, Studies in Aeschylus (Cambridge, 1983), 78-100 dealing with the relation between Zeus and the Erinys in Agamemnon.

${ }^{45}$ Cf. Kyriakou (n. 6), on IT 1276-7 (p. 406).

${ }^{46}$ Cf. Cropp (n. 6), on IT 1276-9 (p. 252): 'he ended the nocturnal declarations, etc.: Zeus has not abolished dreams but has cunningly stopped them from speaking plainly to humans (as described in 1264-7) and so from competing with Apollo's oracular utterances (which themselves were évotás, declarations: cf. El. 1302). By thus depriving the dreams of their candour

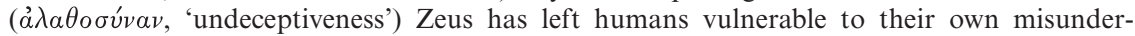
standings of the dreams (like Iphigenia at the beginning of the play)'.

${ }^{47}$ On the sort of dreams described in Homer, see e.g. E.R. Dodds, The Greeks and the Irrational (Berkeley and Los Angeles, 1951), 104-10 and I.J.F. De Jong, A Narratological Commentary on the Odyssey (Cambridge, 2001), on Od. 4.795-841 (pp. 120-2).

${ }^{48}$ Cropp (n. 6), on IT 52 (p. 177) thinks that 'we should probably imagine this [the voice in the dream] as inarticulate moaning', following Devereux (n. 3), 292-3. However, if Iphigenia had heard the pillar moan, she would probably not have spoken of a human voice. Neither is it probable that Orestes would mourn in the dream, as there are no equivalents in the play indicating that Orestes mourns when Iphigenia is present.

${ }^{49}$ Cf. Lennig (n. 2), 199. 
both the supposed deceitfulness of Iphigenia's dream in the chorus's perspective and the dream's misleading aspect from the audience's point of view. Again, there is a wedge: on the basis of Iphigenia's dream, the chorus thinks that dreams are not true, while the audience concludes that dreams do come true.

\section{The aftermath: an auspicious fulfilment of the dream (1284-499)}

The mock purification is narrated by the messenger (1327-1419) but his story is not completely reliable as he has not seen what has happened. Iphigenia performs the purification in secret and the messenger can only tell of the sounds he heard, to which he adds his interpretation. Moreover, the messenger may be inclined to offer a biased report, for he has to explain to Thoas how the Greeks got away from him. Now that the barbarians appear to have been deceived, it is not clear what, if anything, is truthful about the plan Iphigenia has announced. Again, attention is drawn to the act of interpreting. As such, it does not become clear whether Iphigenia really carries out the purification or whether she only pretends, 1336-8:

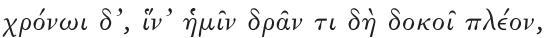

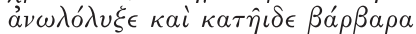

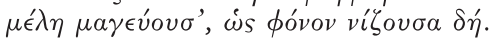

In time - to give an impression, of course, of doing something - she raised an ululation and started reciting barbarian chants, playing the magician, as if she were cleansing the bloodguilt.

Either way, the trick works: the purpose of escape is achieved. ${ }^{50}$

Because Iphigenia has discarded the dream as false, only the audience has the possibility of finding the correct meaning of $v \delta \rho \alpha i v \epsilon \iota v$ and the correct interpretation of the dream. It has to wait till the end of the plot to know the outcome of $v \delta \rho a i v \epsilon \iota$ and to find out whether the purification will bring salvation for the Greeks or the escape will fail because the trick is seen through. The outcome of the dream in the prologue is left unresolved till the play's end and runs as an interpretive puzzle through the play. The audience has to adapt its interpretation of the dream completely: the ominous associations raised by the image of Iphigenia sprinkling water, do not come true. In contrast with the sinister reputation of tragic dreams, this dream is fulfilled in a 'friendly' way. In the end, the dream is not about the actual outcome: the act of $\dot{v} \delta \rho i$ í $\epsilon \iota \nu$ with its open-ended aspect needs to be followed by something: the success or failure of the escape attempt. As such, not even in the 'correct' interpretation does the dream reveal the outcome of events.

\section{THE DREAM'S COMPLEX DRAMATIC FUNCTION}

The dream has a complex dramatic function because of its different impacts on Iphigenia and the audience. For Iphigenia and the development of the plot, the dream turns out to be a dangerous impediment. Iphigenia's misinterpretation initially makes her aggressive towards strangers and almost prevents her from fetching the letter, which delays the recognition between brother and sister. If the dream had not made Iphigenia think Orestes was dead, she could have come up with the letter immediately when she heard the men were from Argos.

${ }^{50}$ On the complex function of deceit in the play cf. K.V. Hartigan, 'Salvation via deceit: a new look at the Iphigeneia at Tauris', Eranos 84 (1986), 119-25 and C. Wolff, 'Euripides' Iphigeneia among the Taurians: aetiology, ritual and myth', CA 11 (1992), 308-34. 
Because dreams in general can both inform about the future and warn or urge the dreamer to do something, one can ascribe two functions to Iphigenia's dream. The dream contains the warning that Orestes is close by and that Iphigenia will sacrifice him if she is not careful. This warning function fails because of Iphigenia's misinterpretation and even threatens to change into a prophesying one. ${ }^{51}$ In the end, the dream's prophecy turns out to refer to the mock purification and the escape plan.

At first the dream makes a malevolent impression as the images in the dream call forth ominous associations. However, if Iphigenia had in the beginning interpreted the dream in the same way as the audience, she might have understood the dream's message as a warning (Orestes is nearby and about to be sacrificed) to anticipate Orestes' arrival and her escape. As such, the dream, though ominous in appearance, would have played a redemptive role. Should one, however, keep the dream 'responsible' for Iphigenia's misinterpretation, which almost leads to Orestes' death? One may be reminded of Oedipus who fulfils the oracle precisely because he misunderstands and acts upon it (which in his case means an attempt to avoid the prophesied evil).

The dream's ambiguity makes the audience experience the difficulties of interpretation. The correct interpretation is revealed only by a process of 'gradual unfolding'. The dream plays with the expectations of the audience. Euripides uses it as a device to create suspense. As the plot moves forward the dream constantly raises expectations that are either fulfilled, postponed, partially fulfilled and partially denied or downright frustrated. ${ }^{52}$ The audience is shown that an ominous meaning of the sprinkling activity is an interpretation and that its interpretation can be as wrong as Iphigenia's: the interpretation is just a hypothesis. ${ }^{53}$ Expectations about what will happen are based on human understanding and human assumptions, which both have their limitations, and do not necessarily come true. This conclusion fits in very well with a main theme in the IT about the human limitations in understanding the divine, described by Cropp (n. 6), 37: 'what happens to us is so variable and unpredictable that we can never know what to expect next, nor why what happens happens - not because there are no gods' designs and no pattern, but because the designs and the pattern are obscure and complicated'. 54

This theme is illustrated throughout the play in other ways as well. ${ }^{55}$ Though

${ }^{51}$ Cf. Devereux (n. 3), 299 on the circularity of time in the dream: "while dreaming, Iphigeneia's behaviour "prophetically" anticipates what she will (almost) do in reality; yet, on awakening, she treats her dream as retrocognitive. Misleading as a clue to the past, her dream also fails as prophecy. This is brilliant, persuasive and poetic psychology: she sacrifices in the dream, but not afterwards'.

52 On the process of gradual unfolding and creating suspense, cf. I.L. Pfeijffer, Three Aeginetan Odes of Pindar. A Commentary on Nemean V, Nemean III, \& Pythian VIII (Leiden, Boston and Cologne, 1999), 41-5, 73, 527, 530, 540, 561.

53 Cf. Wolff (n. 50), 331-4, who gives a list of occasions in the play where the audience's attention is drawn to the process of interpretation.

${ }^{54}$ See also Kyriakou (n. 6), 13-19. The interaction between divine and human may be even more complicated: Kyriakou (n. 6), on IT 55b-58 (p. 66) argues that though the dream seems to predict something that will not actually take place in the play (i.e. the consecration of Orestes for sacrifice), 'the dream is not necessarily mistaken or misleading. Perhaps the original divine plan included Orestes' consecration but Iphigeneia's actions, which will bring about the recognition, will not allow the consecration to take place. Ion, for instance, offers a striking example of Apollo's need to change his initial plan, announced in the prologue (67-73) by another god (Hermes), because of human action (1553-68)'.

55 Wright (n. 6), 362-84 comes to a similar interpretation in his extensive discussion of human 
Orestes' oracle is clearer than the dream, it has not given its information in full. In addition, Apollo does not seem to do anything to have his oracle fulfilled positively and to help Orestes. Orestes doubts Apollo's intentions a few times because of this. For example, when Orestes is on the verge of being sacrificed, he accuses Apollo of having deceived him, 711-15 (Orestes speaking to Pylades):

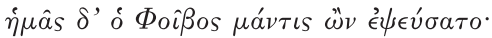

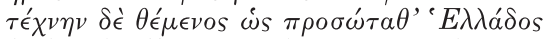

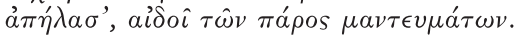

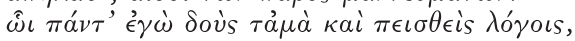

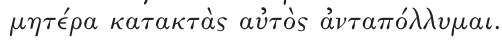

Phoebus the seer played me false and by a trick he drove me as far from Hellas as possible, in shame at the pronouncements he made before. I trusted my whole fate to him and obeyed his words, and killed my mother - and now perish in my turn!

The issue, however, of understanding the gods' wishes and intentions, goes back much further, right to the moment when the misfortune of Iphigenia and her family started: Calchas' divination in Aulis, which led to Iphigenia's sacrifice. In the prologue Iphigenia tells us that Calchas deduced the need to sacrifice her from burnt offerings (15-24). Nowhere in the play, however, does it become clear whether Artemis really wished Iphigenia's sacrifice or human sacrifice in general. ${ }^{56}$ The fact that she saved Iphigenia at the very last moment seems to point to the contrary. ${ }^{57}$ So here we face the same issue - human ability to understand the gods' wishes and intentions is limited with all its consequences.

\section{CONCLUSION}

I have shown Iphigenia's misinterpretation of her dream and its consequences, as well as the way the audience's expectations about the right interpretation shift as the plot moves forward. Eventually the dream proves true: the standing pillar in the dream refers to Orestes who is still alive, and Iphigenia's sprinkling to the washing of Orestes in the sea. Correctly interpreted, the dream turns out to predict the play's plot, although the interpretation does not correspond with Iphigenia's or the audience's interpretation in the beginning. Expectations are raised, and on the basis of these expectations the audience comes to some 'hypothesis' as to how the dream should be interpreted. Every once in a while, however, there is a turn that thwarts the expectations and forces the audience to adjust its hypothesis. The audience can come to the 'correct' interpretation only in the end, because only then it is clear whether the expectation has come true. The shifting interpretation is made possible by the various situations to which the verb $\dot{v} \delta \rho i v \epsilon \iota v$ can apply. The audience has its own experience of a major theme of the play: the difficulty of understanding the divine. Euripides plays with audience expectations, which are based on the notorious ambiguity of

difficulties in interpreting the universe and especially the role of the gods in relation to $\tau u ́ \chi \eta$ in the $I T$ as well as Helen and Andromache.

${ }^{56}$ Cropp (n. 6), 39 and on IT 20-4 (pp. 173-4).

57 Iphigenia thinks the Taurian people, themselves murderous, ascribe their own fault (of making human sacrifices) to Artemis (389-90). Iphigenia uses the word $\alpha \nu \alpha \phi \epsilon ́ \rho \epsilon \nu$ both in 23 and

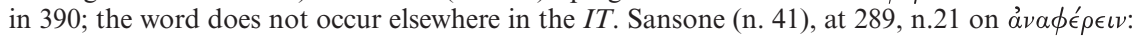
'the word is the mot juste for referring to the way in which men cover over their wickedness by blaming it on the gods. And the verbal echo underlines the connection between Calchas and the savage Taurians'. 
dreams and on the audience's foreknowledge of the myth and the earlier tragedies concerning Iphigenia's family. The dream has turned out to be a mirror-text: it mirrors the play in a dramatic and thematic sense. ${ }^{58}$

Radboud University Nijmegen

CAROLINE P. TRIESCHNIGG

c.trieschnigg@let.ru.nl

58 On the concept of mirror-text see L. Dällenbach, The Mirror in the Text (Chicago, 1989) (translation of Le Récit spéculaire: essai sur la mise en abyme [Paris, 1977] by Jeremy Whiteley with Emma Hughes) and M. Bal, Narratology. Introduction to the Theory of Narrative (Toronto, $1997^{2}$ ) (translation of De theorie van vertellen en verhalen [Muiderberg, 1980²] by C. van Boheemen), 57-8. R. Aélion, 'Songes et prophéties d'Eschyle: une forme de mise en abyme', Lalies 3 (1984), 133-46 shows how dreams and prophecies can work as a mirror text in Persae, Agamemnon and Choephori. Cf. Y. Rinon, 'Mise an abyme and tragic signification in the Odyssey: the three songs of Demodocus', Mnemosyne 59 (2006), 208-25 with bibliographical references. 